\title{
PREVALENCE OF Salmonella spp. IN WATER SOURCES OF SISTAN: A DESCRIPTIVE CROSS-SECTIONAL STUDY
}

\author{
Kambiz Nazemi ${ }^{1}$, Saeed Salari ${ }^{1, *}$ and Majid Alipour Eskandani ${ }^{2}$ \\ ${ }^{1}$ Department of Pathobiology, Faculty of Veterinary Medicine, University of Zabol, Zabol, Iran \\ ${ }^{2}$ Department of food hygiene and quality control, Faculty of Veterinary Medicine, University of Zabol, Zabol, Iran \\ Received - November 14, 2016; Revision - December 02, 2016; Accepted - December 29, 2016 \\ Available Online - December 30, 2016
}

DOI: http://dx.doi.org/10.18006/2016.4(VIS).748.755

KEYWORDS
Salmonella spp.
Water
Prevalence
Sistan

\begin{abstract}
This study was aimed to survey the prevalence of Salmonella spp. in water sources of Sistan and Baluchistan Province, Iran. Total 100 samples were collected from different sites and divided on the basis of potability, geographic location, accessibility, consumption and water flow types. Protocols issued by Institute of Standards and Industrial Research of Iran were used to detect Salmonella spp. Results of study revealed that $74.6 \%$ water sources shows the presence of Salmonella spp. Among studied sources, only one sample of potable water was contaminated with Salmonella spp. The highest contamination was reported from still water and it was significantly different that the pipe water $(\mathrm{p}<0.05)$. The highest contamination among non-potable water was reported from Jazinak compared to other regions. Further, it was reported that non-potable water is mostly used for non-agricultural consumption and it was found to be more polluted than water used for irrigation $(\mathrm{p}<0.05)$. The highest contamination with Salmonella was reported in ponds water $(\mathrm{p}<0.05)$. Non-potable water collected from east region of Sistan was reported more polluted than the west region. Contamination of non-potable water resources in the study area was high. Potable water, totally, indicates the proper function of the Salmonella treatment plan of water refinery of Sistan. Non-potable water of study area is polluted. Identification of Salmonella serotype and antibiotic susceptibility testing serve as indicators to define the accurate level of contamination.
\end{abstract}

* Corresponding author

E-mail: Saeedsalari@uoz.ac.ir (Saeed Salari)

Peer review under responsibility of Journal of Experimental Biology and Agricultural Sciences.

Production and Hosting by Horizon Publisher India [HPI] (http://www.horizonpublisherindia.in/).

All rights reserved.
All the article published by Journal of Experimental Biology and Agricultural Sciences is licensed under a Creative Commons Attribution-NonCommercial 4.0 International License Based on a work at www.jebas.org.

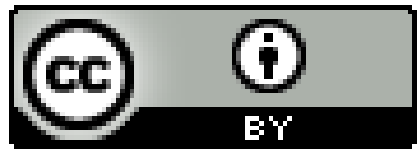




\section{Introduction}

Contaminated water plays an important role in diseases transmission and it performs a vital role in the public health and survival of organisms, especially in rural areas of developing countries (Makoni et al., 2004; Pant, 2004; Katsi et al., 2007). People from developing countries encountered with higher risk of water-borne diseases as compared to the developed countries (Simpson et al., 2002). Based on the report of World Health Organization (WHO), the mortality rate of diseases related to contaminated water is more than 5 million people per year. Nowadays, efforts to attain higher quality of drinking water were emphasized (WHO, 2008).

Microorganisms are of notable importance in many aspects of water quality control and drinking water could transfer diseasecausing bacteria, viruses and parasites (Tebbutt, 1977; Cabral, 2010). Generally, drinking water contains two categories of microorganisms first is known as persistent microorganisms which naturally settle in water, with little food needs, and it includes Acinetobacter, Flavobacerium and Chromobacterium species while other group is transient microorganisms which are transmitted to water from the environment, soil, human or animal, and pathogens fall into this category (Barati, 2011). On global scale, drinking water pollution by pathogens is evaluated the most important risk for human health, and also it has been lead to numerous outbreaks of diseases and poisoning (WHO, 2008). Microorganisms that cause disease via ingestion of contaminated water includes species such as Salmonella, Shigella, Escherichia coli, Vibrio cholerae, Campylobacter jejuni, Cryptosporidium, Entamoeba histolytica, Giardia and Balantidium coli (Cabral, 2010).

Enterobacteriaceae is one of the most important families among bacteria, is of great importance in medicine, industry and research areas and Salmonella spp. is a member of this family. It is gram-negative, motile and considered as the most important human and animal pathogen (Ramírez-Castillo et al., 2015). Recent studies showed that Salmonella has more than 2,500 serovar and among these $S$. enteritidis and $S$. typhimurium are the most important one and the most isolated serotypes from water (Tabatabayi \& Firouzi, 2002; Popoff \& Le Minor, 2005; Tortora, 2008; Salem \& Metawea, 2013). Eating contaminated food or drinking contaminated water is the one of the major routes of Salmonella transmission (D'Aoust, 1989; Quinn et al., 2002; Brooks et al., 2015). Salmonella infection in humans is mainly caused by drinking water contaminated with secretions and feces of infected animals (Zahraei Salehi, 2000; Quinn et al., 2002; Winn et al., 2006; Motlagh et al., 2013).

One of the most common diseases caused by Salmonella in humans is typhoid fever which mostly spreads through contaminated food and water. Symptoms of typhoid fever in humans include fever, headache, abdominal pain, nausea, vomiting, diarrhea, gastroenteritis and septicemia (Acha \&
Szyfres, 2003; Bergeron et al., 2011; Chandra et al., 2013). According to Seas et al. (2000) children under five years-age, mainly in Asian and African countries are considered to be the most significant group of patients infected with waterborne microbial disease. Sources of drinking water, in many rural areas, are severely associated with the failure of quality control (Guppy \& Shantz, 2011), and at the best form, it is only carried out once when water plans startup (Rossiter et al., 2010). Increased water scarcity on the one hand and low quality on the other hand, especially in many developing countries, are serious problems and have derived from misuse and mismanagement of water resources in these areas (Kakonge, 2002; Saravanan et al., 2011). Since no research has been conducted regarding the prevalence of one of the most important pathogens transmitted through water in Sistan city, the present study was performed to determine the prevalence of Salmonella spp. in water sources of Sistan region, Sistan and Baluchistan province, Iran, using conventional methods.

\section{Materials \& Methods}

\subsection{Sample Collection and Classification}

This is a descriptive, cross-sectional study in order to determine the prevalence of Salmonella in water sources of Sistan. Study was conducted for 5 months (March 2014, to July 2015), water samples were collected from different water sources and areas of Sistan, including three main political division (Figure 1). Zabol is a city in Sistan and Baluchestan Province, Iran, and lies on the border with Afghanistan. Zabol is located near Lake Hamun and the region is irrigated by the Hirmand River. Lake Hamun is a seasonal lake that is often dry and included three parts (Figure 1). Zabol is connected by road to Zaranj across the border in Afghanistan (Karimi et al., 2013). Sterile glass bottles with a volume of $300 \mathrm{ml}$ were used for sampling. Tape water samples were collected as follow: for a minute, the faucet was left open and then water was gathered. In the cases where there was no direct access to water (shallow wells, agricultural canals, rivers and etc.) a rope was used: the bottles were tied up tightly, and then, completely immersed in water. As far as possible, by dipping the bottles, efforts were made to collect water from deeper parts of sites in order to prevent of exposure to air and surface contamination (about 30 $\mathrm{cm})$.

In all cases, after obtaining the sample, the top of the bottles was sealed by parafilm and covered by an aluminum paper. The bottles were tagged, coded and transferred to Laboratory of Microbiology, Faculty of Veterinary Medicine, University of Zabol, Iran. Due to the distance and environment temperature, if necessary, the samples were delivered in the presence of ice. In total, 100 samples were collected randomly with an average of three replications. A total of 80 samples, based on the way of water flow were divided into three categories: still water $(n=31)$, running water $(n=19)$ and pipeline water $(\mathrm{n}=30)$. 


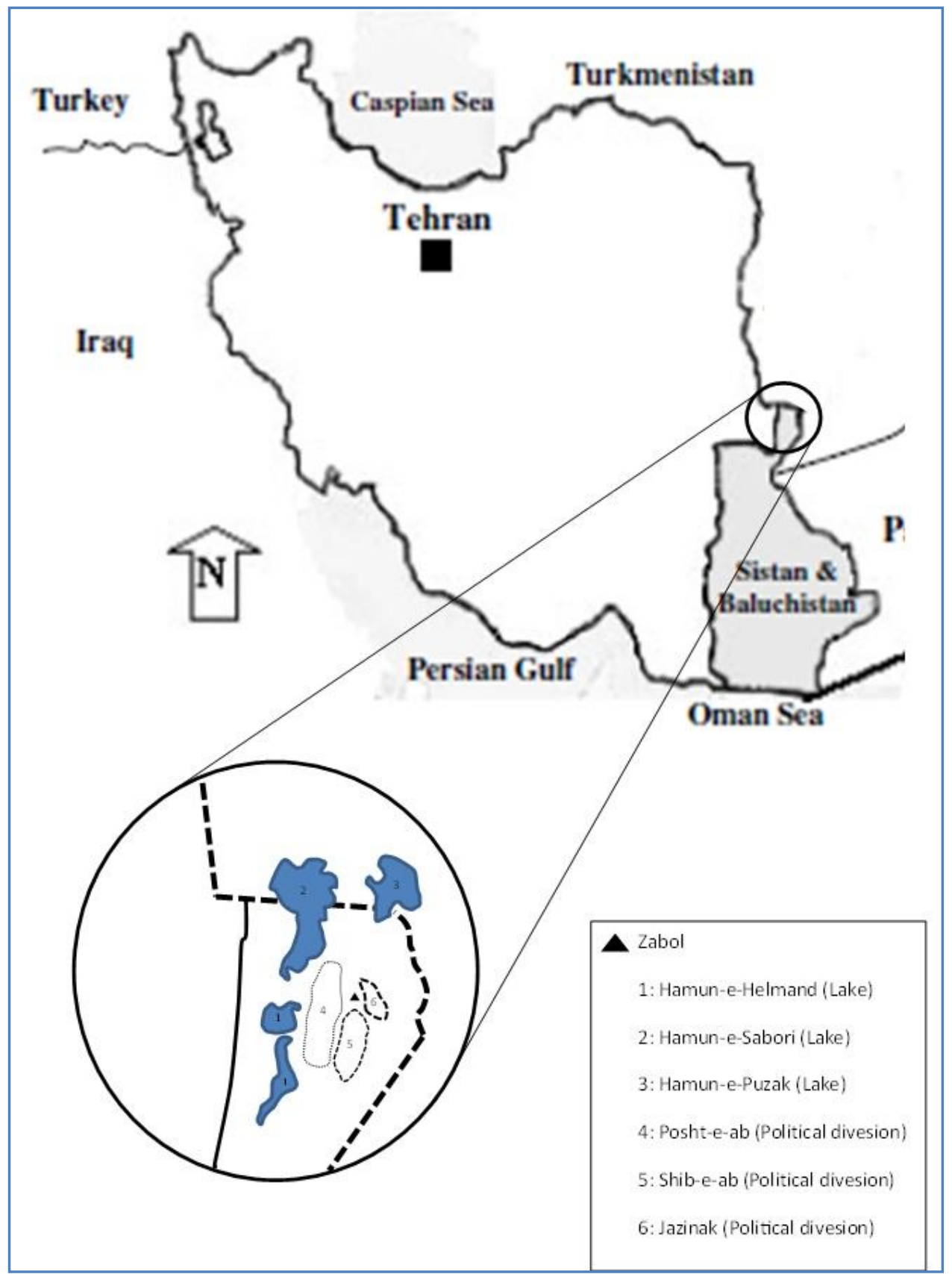

Figure 1 Sampling Sites in the present study.

Also, 80 samples, based on the drinkability, were divided into two groups: potable $(n=30)$ and non-potable water $(n=50)$. Non-potable water was divided into three categories based on the state divisions: Sheyb-e-Ab ( $\mathrm{n}=11)$, Posht-e-Ab ( $\mathrm{n}=9)$, and Jazinak $(n=28)$, into two categories based on consumption: used for irrigation $(n=17)$ and non-irrigation $(n=33)$ purposes, into five categories on the basis of water access: channel $(\mathrm{n}=10)$, river $(\mathrm{n}=7)$, pond $(\mathrm{n}=27)$, well $(\mathrm{n}=2)$ and dam $(\mathrm{n}=4)$ water, and into two categories based on the topography of Sistan: waters collected from East $(n=28)$ and West region of Sistan $(n=20) .20$ samples of potable water that had been taken from different districts of Sistan, based on the geographical location were divided into two categories: eastern $(n=8)$ and western $(n=12)$ regions of the city.

\subsection{Investigation the presence of Salmonella}

Protocol No. 8789 issued by Institute of Standards and Industrial Research of Iran was used to detect the presence of Salmonella spp. (ISIRI, 2009). Briefly, three phases including pre-enrichment, enrichment and cultures in special and differential media were used. 
In the pre-enrichment stage, $25 \mathrm{ml}$ of water sample was added to $225 \mathrm{ml}$ of Lactose Broth (Merck, U.S.A) and was incubated for 48 hours at $37{ }^{\circ} \mathrm{C}$. Then, as enrichment phase, $1 \mathrm{ml}$ of cultured Lactose Broth was added to the tube containing $10 \mathrm{ml}$ of Tetrathionate broth (Merck, U.S.A) and also, $1 \mathrm{ml}$ of cultured Lactose Broth was added to the tube containing $10 \mathrm{ml}$ of selenite cystine broth (Himedia, India). These tubes were incubated for 24 hours at $37{ }^{\circ} \mathrm{C}$.

In the third stage, a loopful of the tetrathionate and selenite cystine broths were inoculated on Salmonella Shigella Agar (SSA) plates (Merck, USA). The cultured media were incubated for 24 hours at $37{ }^{\circ} \mathrm{C}$. Suspected colonies grown on SSA were subcultured on TSI agar (Liofilchem, Italy), SIM agar (Merck, USA), Simon citrate (Liofilchem, Italy), urea broth (Merck, USA), Methyl Red broth (Himedia, India), and Voges-Proskauer broth (Himedia, India) to confirm the presence of Salmonella. Salmonella organisms appeared as transparent or translucent colorless colonies with black dot on SSA. An alkaline/acid (red slant/yellow butt) reaction was indicative of Salmonella with a blackening of the medium. On SIM, A positive $\mathrm{H}_{2} \mathrm{~S}$ test was denoted by a blackening of the medium along the line of inoculation and a positive motility test was indicated by a diffuse zone of growth flaring from the line of inoculation. A yellow color denoted a negative indole test after addition of Kovacs Reagent by Salmonella. A positive reaction was indicated by growth with development of a deep blue color reaction within the medium. Methyl red and Voges-Proskauer tests were positive and negative for Salmonella, respectively. The solution remaining yellow for methyl red indicated a negative test. After adding both alphanaphthol and potassium hydroxide as reagents to VogesProskauer test, the tube was shaken vigorously, and then allowed to sit for 5-10 minutes. A pinkish-red color indicates a positive test (Quinn et al., 2002).

\subsection{Analysis of Data}

Data were analyzed with SPSS and K-square test. Significance value was considered to be less than 0.05 .

\section{Results}

Result of study revealed that $74.6 \%$ water sources of the Sistan area have Salmonella contamination (Table 1). According to the results, types and status of water samples affect the Salmonella contamination in study area. Among the studied samples highest Salmonella contamination (31.2\%) was reported from still water, it was followed by the running water (15\%) and tap (pipeline) water (1.2\%). K-square test showed a significant relationship between the water flow and the Salmonella contamination in such a way that the still water had the highest contamination and pipe water had the lowest contamination ( $\mathrm{p}<0.05$ ). The Salmonella contamination was observed $46.2 \%$ and $1.2 \%$, in non-potable and potable water, respectively. K-square test showed that the Salmonella contamination is significantly higher in non-potable water compared to potable water ( $\mathrm{p}<0.05$ ). The results demonstrated that the Salmonella contamination in Jazinak, Posht-e-Ab and Sheyb-e-Ab regions are $37.5 \%, 18.7 \%$ and $16.7 \%$, respectively; although the highest contamination was observed in Jazinak but this difference was not significant ( $p>0.05$ ).

Based on the results, Salmonella contamination in non-potable water used for irrigation and non-irrigation consumption was reported $12 \%$ and $62 \%$, respectively. With a significant difference, the water used for non-irrigation purposes is significantly higher contaminated compared to water used for irrigation purposes $(\mathrm{p}<0.05)$. The results showed that Salmonella pollution was $50 \%$ in ponds, $12 \%$ in rivers, $6 \%$ in channels and $6 \%$ in dams. Further, it was reported that well water have less or almost nil contamination. K-square test showed that this difference was significant $(\mathrm{p}<0.05)$. Salmonella contamination of non-potable water in East and West regions of Sistan was 36\% and 34\%, respectively and based on K-square test, there was no significant difference ( $p$ > 0.05 ) was reported among various treatments. Among potable water samples, only one (5\%) was Salmonella contaminated, which was located in the West of the city and K-square test showed a statistically significant difference $(\mathrm{p}<0.05)$. The rest of potable water samples collected from different areas of the city were negative for Salmonella.

\section{Discussions}

Today, there is no cost-effective substitute instead of water. As a result, water conservation and re-use would be wisely (Mercer, 1964; EL-Jakee et al., 2009). The water which has no negative effect on growth, reproduction and productivity of livestock and poultry is considered as healthy water and this is the fundamental basis for the growing healthy animal (Tebbutt, 1977; Duguma et al., 2012). At global scale, contamination of potable water by pathogenic bacteria leads to the main hazards to human health. Countless outbreaks of water-borne diseases are the result of the exposure of organisms to untreated or poorly treated water (Faruque et al., 1998; WHO, 2008; Salem \& Metawea, 2013). To best of our knowledge, this study is the first report which assesses the prevalence of Salmonella spp., as a zoonosis and water born pathogen, from the border region water sources of the Sistan, Iran. Salmonella spp. is considered as a most common cause of food-borne infection throughout the world (D'Aoust, 1989; Baird-Parker, 1990; Waage et al., 1999). Although the concentration of Salmonella in the water has been measured low but the consumption of contaminated water with this bacterium will be lead to infection, because the water can quickly pass through the stomach and then, enter to the intestines, without triggering the mechanisms of digestion and thereby the microorganism escapes the natural host defense systems. In addition, Salmonella can survive for a months in water (D’Aoust, 1989; Murray, 1991; Waage et al., 1999; Salem et al., 2011). 
Table 1 prevalence (\%) of Salmonella in various samples of study area.

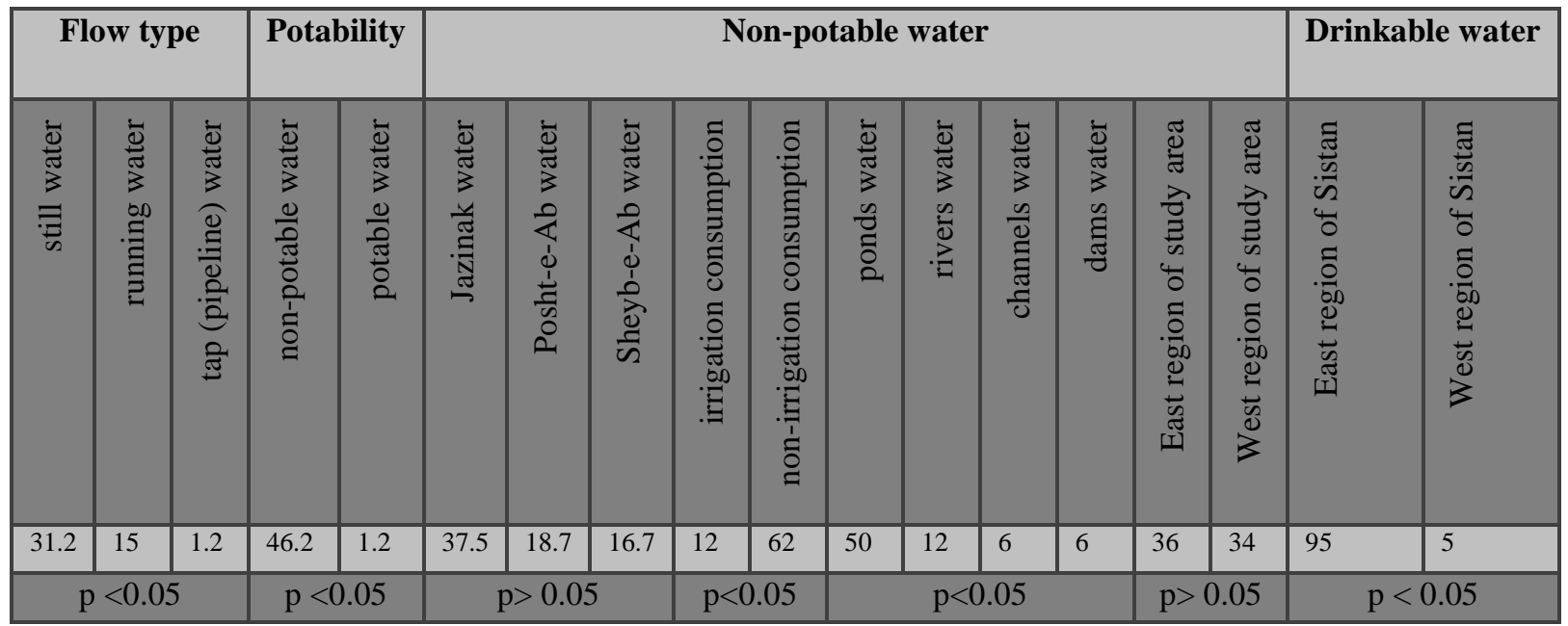

The contamination of water with Salmonella spp. in the study area was observed $74.6 \%$, as a first report. Few previous studies related to the Salmonella contamination in the water sources of various regions of the Iran was investigated by the various researchers. In this context, Momtaz et al. (2013) examined the presence of Salmonella spp. in packaged potable water and tap (pipeline) water in Iran. These researchers investigated the quality and contamination of potable water in Isfahan by PCR. Their results showed that $2.08 \%$ of the samples were contaminated with Salmonella. Further, Jafari et al. (2006) tested the pollution of drinking water with Salmonella in 40 broiler farms located in the rural areas of Ahvaz, Iran and reported the presence of Salmonella from five broiler farms.

The presence of Salmonella spp. in water sources can be a serious danger for the human an animal community. Because of high contamination of water sources with Salmonella spp. in the Sistan region, further examination is required in order to achieve the origin of contamination and purgation of the sources. In present study, variation in the percentage of water contamination with Salmonella was reported from the still water and it was followed by running water, and pipes water that have had the least contamination. Still water has higher contamination than the running water and the $\mathrm{K}$-square test revealed the significant difference.

It was found that there was a significant relationship between the water flow and the amount of Salmonella contamination. Indeed, the surface water that has movement, have less contamination than still surface water. Studies showed that water pollution was higher among those who stored water and used it later on. In fact, storage of water beside the immobility, especially in storage devices, in addition to the animal feces and also birds that loaf freely in home, even rodents and arthropodes like flies, as a mechanical carrier, can be act as factors to increase the pollution of water. Further investigations are required for the correct estimation of Salmonella population (Osman et al., 2010; Salem \& Metawea, 2013).

In present study, Salmonella contamination in non-potable water was significantly higher than potable water and as mentioned earlier, this represents the proper function plan designed for water treatment of Sistan for Salmonella. The reported contamination also needs further inquiry to determine the predominant serotypes of this bacterium and their association with human diseases to increase the quality of water sanitation, effectively. In this study, analysis showed no significant difference among non-potable water of Sheyb-e-Ab, Posht-e-Ab and Jazinak regions, albeit, the descriptive results show higher contamination of water collected from Jazinak, followed by Posht-e-Ab. This issue might be related to existence of more water resources in Jazinak region for agriculture and livestock consumption. In this study, descriptive results showed Salmonella contamination of nonpotable water used for non-irrigation purposes is higher compared to non-potable water used for irrigation purposes; and analytical results showed a statistically significant difference.

Major sources of surface contaminants include animal feces and other animal activities, leakage of contaminated material from shallow lakes or ponds, and landfill locations where debris and waste accumulate without sanitary mechanisms; on the other hand, groundwater contaminants sources consist of, for example, the contaminated tank with systems malfunction, underground tanks for domestic liquid sewage (sinkholes) or leaking underground sewer lines (Berger, 2012; Salem \& Metawea, 2013). Each of the above-mentioned factors can lead to contamination in the region, however, further researches should be carried out in this regard. The descriptive results, regarding non-potable water, showed that the ponds were the most polluted, followed by rivers, channels and dams with similar degree of contamination, and ultimately wells with least contamination. K-square analysis showed, significantly, 
the relationship between the way of access to non-potable water and contamination with Salmonella. Role of environmental pollutants of surface water in the study area could explain the cause of this result. Due to water rinsing, through seasonal raining, especially in confronting with environmental contaminant and feces of animal in different areas, the amount of microbial contamination would be increased in ponds (Mahmodi \& Javanmardi, 2009).

The descriptive results regarding non-potable water contamination with Salmonella showed that contamination in East area of Sistan was higher than West area but analytical results did not detect significant differences. Salmonella detection in water may be conflict by low number and sometimes their intermittent presence (D'Aoust, 1989; Waage et al., 1999). In the current study, only one sample of drinking water was Salmonella-contaminated and the rest of potable water was negative for Salmonella. Studies showed that water contamination with Salmonella can be due to biofilm formation of opportunistic bacteria in the water distribution system, especially in surface of damaged pipelines, and release the bacterium in water (Edberg,1996; Adesoji \& Ogunjobi, 2013). Further investigation must be carried out to find out the origin of reported contamination. Our results may be due to increased resistance of bacteria to the high concentration of chlorine or other disinfectants used in the study area, albeit further studies are required to clarify this issue (Adesoji \& Ogunjobi, 2013).

In conclusion, present study indicated that the water sources of Sistan region were severely contaminated with Salmonella spp. and identification of different serotypes of Salmonella in the study area would be worthwhile. On the other hand, the efficiency of water treatment system in Sistan, according to the results of this study, was reported well for Salmonella spp. Our study contributes in the assessment of water quality in Sistan, Iran. Although other water quality indicators need to include, but alarming signal for human consumption and public health was observed. Management of wind, Salmonella serotype identification and finally antibiotic susceptibility testing could be suggested to find out the risk factors of pollution.

\section{Acknowledgements}

This study was carried out in partial fulfillment of the requirements for DVM student's thesis (Kambiz Nazemi). We appreciate the support provided by the personnel of the laboratory of microbiology.

\section{Conflict of interest}

Authors would hereby like to declare that there is no conflict of interests that could possibly arise.

\section{References}

Acha PN, Szyfres B (2003) Zoonoses and Communicable Diseases Man and Animals, Pan American Health
Organization, Scientific and Technology, Publications, Washington, DC.

Adesoji AT, Ogunjobi AA (2013) Occurrence of MultidrugResistant Bacteria in Selected Water Distribution Systems in Oyo State, Nigeria. World Applied Sciences Journal 28: 21362146. DOI: 10.5829/idosi.wasj.2013.28.12.919.

Baird-Parker AC (1990) Foodborne salmonellosis. The Lancet 336: 1231-1235. DOI: http://dx.doi.org/10.1016/01406736(90)92844-8.

Barati B (2011) Protocols of Microbiology Lab. 1st ed. Jafari Press. Tehran (Text in Persian).

Berger PS (2012) Microbes in groundwater in water Encyclopedia. Available on http://www.encyclopedia.com/doc/1G2-3409400209.htm accessed 22 June 2016.

Bergeron P, Oujati H, Catalán Cuenca V, Huguet-Mestre JM, Courtois S (2011) Rapid monitoring of Escherichia coli and Enterococcusspp. in bathing water using Reverse Transcription-quantitative PCR. International Journal of Hygiene and Environmental Health 214: 478-484. DOI: http://dx.doi.org/10.1016/j.ijheh.2011.07.013.

Brooks GF, Carroll KC, Butel JS, Morse SA, Mietzner TA (2015) Jawetz, Melnick, and Adelberg's Medical Microbiology, 26 ed. McGraw-Hill Education. USA.

Cabral JPS (2010) Water Microbiology. Bacterial Pathogens and Water. International Journal of Environmental Research and Public Health 7:3657-3703. doi: 10.3390/ijerph7103657.

Chandra M, Cheng P, Rondeau G, Porwollik S, McClelland M (2013) A single step multiplex PCR for identification of six diarrheagenic E. coli pathotypes and Salmonella. International Journal of Medical Microbiology 303: 210-216. doi: 10.1016/j.ijmm.2013.02.013.

D'Aoust JY (1989) Salmonella. In: Doyle MP (Ed.), Foodborne Bacterial Pathogens. CRC Press. pp. 327-445.

Duguma B, Tegegne A, Hegde BP (2012) Assessment of the Effect of Season and Location on Microbiological and Physicochemical Quality of Livestock Drinking Water in Ginchi Watershed, Ethiopia. Global Veterinaria 8: 342-346.

Edberg SC (1996) Assessing Health Risk in Drinking Water from Naturally Occuring Microbes. Journal of Environmental Health 58: 18-24.

EL-Jakee J, Moussa EI, Mohamed KhF, Mohamed G (2009) Using Molecular Techniques for Characterization of Escherichia coli Isolated from Water Sources in Egypt. Global Veterinaria 3: 354-362. 
Faruque SM, Albert MJ, Mekalanos JJ (1998) Epidemiology, genetics, and ecology of toxigenic Vibrio cholerae. Microbiology and Molecular Biology Reviews 62: 1301-1314.

Guppy L, Shantz A (2011) Groundwater quality in rural Cambodia: Measures and perceptions. Geographical Research 49: 384-394. DOI: 10.1111/j.1745-5871.2011.00710.x.

Institute of Standards and Industrial Research of Iran (ISIRI). 2009 Water quality- Detection of Salmonella species. ISIRI NUMBER 8789. Available on http://www.isiri.com/ accessed on 14 December, 2016.

Jafari RA, Fazlara A, Govahi M (2006) An Investigation into Salmonella and Fecal Coliform Contamination of Drinking Water in Broiler Farms in Iran. International Journal of Poultry Science 5: 491-493. DOI: 10.3923/ijps.2006.491.493.

Kakonge JO (2002) Water scarcity and related environmental problems in parts of sub-Saharan Africa: the role of the transboundary environmental impact assessment convention. Impact Assessment and Project Appraisal 20: 49-59. DOI: http://dx.doi.org/10.3152/147154602781766861.

Karimi M, Yazdani MH, Naderi A (2013) The effect of 120day winds on the safety of Sistan region. Geography and Environmental Planning 50: 25-27.

Katsi L, Siwadi J, Guzha E, Makoni FS, Smits S (2007) Assessment of factor which affect multiple uses of water sources at household level in rural Zimbabwe. A case study of Marondera, Murehwa and Uzumba Maramba Pfungwe districts. Physics and Chemistry of the Earth 32: 1157-1166. DOI: http://dx.doi.org/10.1016/j.pce.2007.07.010.

Mahmodi MM, Javanmardi F (2009) Determination of amount and source of fecal bacteria in water of Lake Parishan. Iranian Journal of Biology 4:711-718 (Text in Persian).

Makoni FS, Manase G, Ndamba J (2004) Patterns of domestic water use in rural areas of Zimbabwe, gender roles and realities. Physics and Chemistry of the Earth 29: 1291-1294. DOI: http://dx.doi.org/10.1016/j.pce.2004.09.013.

Mercer WA (1964) Physical Characteristics of Recirculated Water as Related to Sanitary Conditions. Food Technology 335: 111-115.

Momtaz H, Dehkordi FS, Rahimi E, Asgarifar A (2013) Detection of Escherichia coli, Salmonella species, and Vibrio cholerae in tap water and bottled drinking water in Isfahan, Iran. BMC Public Health 13:556. DOI: 10.1186/1471-245813-556.

Motlagh H, tavakoli HR, Dabagh moghadam A, Cheraghi N, Akbarin HA (2013) Assessment of Bactaslide media in diagnosis of Salmonella in water and foods in comparison with standard method in order to use in crisis. Annals of Military and Health Sciences Research 11:114-119 (Text in Persian).

Murray CJ (1991) Salmonellae in the environment. Revue Scientifique et Technique. Office International des Epizooties 10: 765-785.

Osman GA, Kamel MM, Al- Herrawy AZ (2010) Microbiological criteria of tap water passed through some storage water tanks in Greater Cairo. Environmental Biotechnology 6: 61-65.

Pant PR (2004) Tailored media for the detection of E.coli and coliforms in the water sample. Tribhuvan University Journal 24: $49-54$.

Popoff MY, Le Minor LE (2005) Genus Salmonella. In: Brenner DJ, Krieg NR, Staley JT (Eds.) Bergey's Manual of Systematic Bacteriology, New York, NY, USA, Pp. 764-799.

Quinn PJ, Markey BK, Carter ME, Donnelly WJ, Leonard FC (2002) Veterinary Microbiology and Microbial Disease. Iowa State University Press, Ames, Iowa, USA.

Ramírez-Castillo FY, Loera-Muro A, Jacques M, Garneau P, Avelar-González FJ, Harel J, Guerrero-Barrera AL (2015). Waterborne Pathogens: Detection Methods and Challenges. Pathogens 4 : $4307-334$. http://doi.org/10.3390/pathogens4020307

Rossiter HMA, Owusu PA, Awuah E, MacDonald AM, Schafer AI (2010) Chemical drinking water quality in Ghana: Water costs and scope for advanced treatment. Science of the Total Environment 408: 2378-2386. DOI: http://dx.doi.org/10.1016/j.scitotenv.2010.01.053.

Salem IB, Ouardani I, Hassine M, Aouni M (2011) Bacteriological and physico-chemical assessment of wastewater in different region of Tunisia: impact on human health. BMC Research Notes 22: 144. doi: 10.1186/17560500-4-144.

Salem LMA, Metawea YF (2013) Detection of Some Water Borne Zoonotic Pathogens in Untreated Ground Water and its Impact on Human and Animal Health in Kalyoubia Province (Rural Areas). Global Veterinaria 10: 669-675. DOI: 10.5829/idosi.gv.2013.10.6.73119.

Saravanan VS, Mollinga PP, Bogardi JJ (2011) Global change, wastewater and health in fast growing economies. Current Opinion in Environmental Sustainability 3: 461-466. DOI: http://dx.doi.org/10.1016/j.cosust.2011.10.009.

Seas C, Alarcon M, Aragon JC, Beneit S, Quiñonez M, Guerra H, Gotuzzo E (2000) Surveillance of Bacterial Pathogens Associated with Acute Diarrhea in Lima, Peru. International Journal of Infectious Diseases 4: 96-99. DOI: http://dx.doi.org/10.1016/S1201-9712(00)90101-2. 
Simpson JM, Santo Domingo JW, Reasoner DJ (2002)

Microbial source tracking, state of the science. Environmental Science Technology 36: 5279-5288.

Tabatabayi AH, Firouzi R (2002) Disease of animals due to bacteria. Tehran University Press. Tehran.

Tebbutt THY (1977) Principles of water quality control. 2nd ed. Pergamon Press, London.

Tortora GA (2008) Microbiology: An Introduction (9th ed). Pearson. pp: 323-324.

Waage AS, Vardund T, Lund V, Kapperud G (1999) Detection of low numbers of Salmonella in environmental water, sewage and food samples by a nested polymerase chain reaction assay.
Journal of Applied Microbiology 87: 418-428. DOI: 10.1046/j.1365-2672.1999.00835.x.

Winn WJr, Allen S, Janda W, Koneman E, Procop G, Schreckenberger P, Woods G (2006) Koneman's Color atlas and textbook of diagnostic microbiology. 6th ed. Lippincott Williams and Wilkins.

World Health Organization (WHO) (2008) Guidelines for Drinking-water Quality, Incorporating 1st and 2nd Addenda, Volume 1, Recommendations, 3rd ed. WHO: Geneva, Switzerland.

Zahraei Salehi T (2000) Salmonella. Tehran University Press, Tehran. 